\title{
Regulation of Aminopeptidase A in Human Brain Tumor Vasculature: Evidence for a Role of Transforming Growth Factor- $\beta$
}

\author{
Lucienne Juillerat-Jeanneret, Sylvia Lohm, Marie-France Hamou, and \\ Florence Pinet
}

Institute of Pathology (LJJ, SL), CHUV, University of Lausanne; Neurosurgery Division (MFH), CHUV, Lausanne, Switzerland; and INSERM U36 (FP), Collège de France, Paris, France

\begin{abstract}
SUMMARY: Angiotensin peptides are potent vasoconstrictors, cell growth factors, and neuromodulators in normal and pathological situations. To assess the potential role of the angiotensins in brain tumor-associated vessels, the expression of the enzymes of the angiotensin cascade were evaluated in these tumors. The production of these bioactive peptides is dependent on the activities of exopeptidases, including several aminopeptidases and carboxypeptidases, producing angiotensin (Ang) I, II, III, IV and Ang 1-7. Human cerebral parenchymal and glioblastoma cells expressed renin, and tumor vasculature, but not glioblastoma cells, expressed angiotensin-converting enzyme. High aminopeptidase A (APA) activity, but no aminopeptidase N/B activity, was observed in human brain tumor vasculature, suggesting a predominant production of Ang III. Grafting of rat glioma cells in rat brains yielded tumors with high APA and low aminopeptidase N/B activities in tumor vessels, confirming human results. Tumor growth and APA activity in tumor vessels were not affected by chronic angiotensin-converting enzyme inhibition. The brain-derived EC219 endothelial cells expressed high APA activity, which was not involved in endothelial cell proliferation, but was down-regulated by exposure of cells to transforming growth factor- $\beta$ (TGF $\beta$ ) or to TGF $\beta$-secreting tumor cells, suggesting a role for this peptide in the control of APA activity in cerebral vasculature. Thus, APA is a potential marker of chronic dysfunction, involving loss of TGF $\beta$ function, of the metabolic blood-brain barrier, but not of neovascularization. (Lab Invest 2000, 80:973-980).
\end{abstract}

$P$ cosent roteolytic enzymes are involved in the activation, degradation, and transformation of bioactive peptides, and the modulation of peptidase activities is an important factor regulating the biological function of peptide hormones. Cellular peptidases also play an important role in signal transduction and communication between cells. Thus, a subtle regulation of peptidase expression and activity is necessary to maintain normal cell function. Tumor vessels have an aberrant response to vasoconstrictor hormones, such as the angiotensins and endothelins. Angiotensin (Ang) peptides, besides regulating vascular tone and natriohydric balance, are involved in the control of cell growth, vascular permeability, and neuromodulation. Recently, using a model of angiotensinogen knock-out mice, the importance of Ang II and Ang IV, but not Ang III, in maintaining a normal blood-brain barrier function has been demonstrated (Kakinuma et al, 1998). Ang II, the vasoactive hormone of the renin-angiotensin system, is produced from angiotensinogen by the se-

Received March 10, 2000.

This work was supported by grants from the Swiss Multiple Sclerosis Society, the Swiss Public Health Office (AIDS Fund, Grant \# 3139-041861.94), and the Swiss and Bern Cancer Foundations (Grant \# SKL 353-9-1996). Address reprint requests to: Dr. Lucienne Juillerat, Institute of Pathology, Bugnon 27, CH1011 Lausanne, Switzerland. Fax: + 41213147175 ; E-mail: lucienne.juillerat@chuv.hospvd.ch quential action of renin (EC 3.4.23.15) and angiotensin converting enzyme (ACE) (EC 3.4.15.1). Ang II degradation begins with the action of aminopeptidase $A$ (APA) (EC 3.4.11.7), which removes the N-terminal Asp to produce Ang III, a potent aldosterone secretagogue and neuronal stimulant but a less potent vasoconstrictor peptide than Ang II. Further N-terminal processing by aminopeptidase N/B-like (APN/B) activity produces the Ang 3-8 (Ang IV) and Ang 4-8 fragments (Ardaillou and Chansel, 1997). Thus, from the common precursor angiotensinogen, several peptides with different biological activities can be obtained by the specific action of different aminopeptidases. The distribution in the vascular tree of these various aminopeptidases is heterogeneous; therefore, different peptides may be produced depending on the particular tissue location and context.

Cerebral microvasculature that forms the bloodbrain barrier differs from the microvasculature of other organs (Joo, 1993). In particular this includes the expression of $\gamma$-glutamyltranspeptidase ( $\gamma$ GTP) (DeBault and Cancilla, 1980) and various aminopeptidases (Juillerat-Jeanneret et al, 1992, Zini et al, 1996) that have been involved in the functions of the metabolic blood-brain barrier. The mechanisms regulating the expression of proteolytic enzymes in the cerebral microvasculature are poorly understood. In particular, the specific expression of peptidases involved in the metabolism of angiotensin peptides in cells forming 
the abnormal vasculature of human brain tumors has not yet been investigated. Brain tumors are highly vascularized, but the tumor vessels demonstrate abnormal features, including increased permeability. Peritumoral cerebral edema, a frequent complication of brain tumors, can be resolved by glucocorticoids. In brain-derived endothelial cells, the anti-inflammatory glucocorticoid dexamethasone decreased APA expression and activity (Juillerat-Jeanneret et al, 1992), suggesting a regulatory role for this enzyme and for the generated angiotensin peptides in the control of cerebral vascular function. In these cells, dexamethasone, as well as transforming growth factor- $\beta$ (TGF $\beta$ ), another anti-inflammatory factor, also regulated inducible nitric oxide synthase (Murata et al, 1995), suggesting a role for anti-inflammatory molecules in the control of cerebral vasculature functions.

Chronic administration to rats of lisinopril, a nonthiol ACE inhibitor, resulted in a decrease of APA activity in the blood and lungs (Juillerat-Jeanneret, 1993). It was recently shown that the intake of captopril, a thiol ACE inhibitor, but not other antihypertensive drugs, decreases the risk of cancer in patients (Lever et al, 1998) and reduces tumor growth in experimental tumors in the rat by controlling angiogenesis (Prontera et al, 1999; Volpert et al, 1996). To address the role of angiotensin peptides in the tumor vasculature in brain cancer, we have evaluated the expression of the peptidases involved in angiotensin metabolism on histological sections of human brain tumors. The high level of APA activity observed in human tumor vasculature was also seen in an experimental model of intracerebral transplantation of rat glioblastoma, suggesting that the active peptide of the angiotensin pathway in brain tumors is Ang III. Intake of a non-thiol ACE inhibitor did not modify tumor growth and aminopeptidase expression in this rat experimental model. To define the potential role of APA in tumor progression, the effects of APA inhibition and TGF $\beta$ in brain-derived endothelial cells (JuilleratJeanneret et al, 1992) were evaluated. Our results indicate that APA is not involved in endothelial growth and that its activity is regulated by $\operatorname{TGF} \beta$ in cerebral endothelial cells.

\section{Results}

The expression of the enzymatic activities involved in the processing of angiotensins was first evaluated in human brain tumors. In normal human brain vasculature, renin immunoreactivity was observed in neurons and in structures apposed to microvessels (Fig. 1, A and B), some astrocytes, and resident macrophages/ microglia (not shown). The specificity of the immunoreactivity for renin was ascertained by using as a negative control the monoclonal antibody 4G1, which recognizes only soluble forms of renin (Galen et al, 1984). This antibody did not recognize any structure in our conditions (not shown). Low intracellular levels of active renin (ranging from 8.6 to $60.9 \mathrm{pg}$ renin/mg protein) could be detected in the human glioblastoma cell lines LN18, LN229, LN319, and LN428 (Diserens et al, 1981), but no renin could be detected in culture supernatants. The four glioblastoma cell lines did not express ACE activity and did not inhibit the activity of purified plasma ACE (not shown). ACE immunoreactivity was found only in cerebral tumor vessels (Fig. 1C), as confirmed by immunostaining for Factor VIIIrelated antigen (Fig. 1D).

High levels of APA activity were found in the vessels of all cerebral tumors that were evaluated, including glioblastoma (Fig. 2A), astrocytoma (Fig. 2B) or meta-
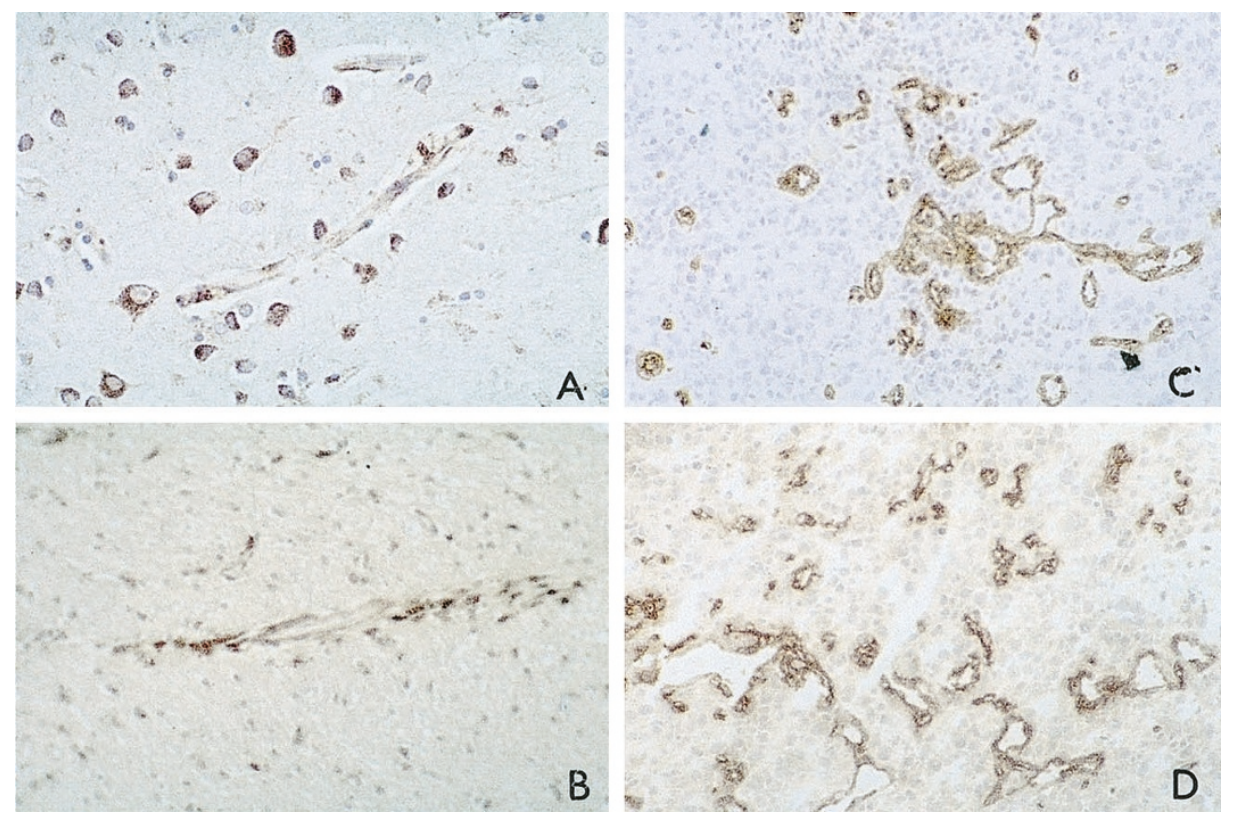

\section{Figure 1.}

Expression of renin and ACE in human brain. Sections of human brain were immunolabeled with monoclonal antibodies against $(A, B)$ human renin (anti-renin antibody 2D12), (C) ACE (monoclonal anti-ACE 9B9), and (D) anti-factor VIII (DAKO). Original magnification: $\times 250$. 

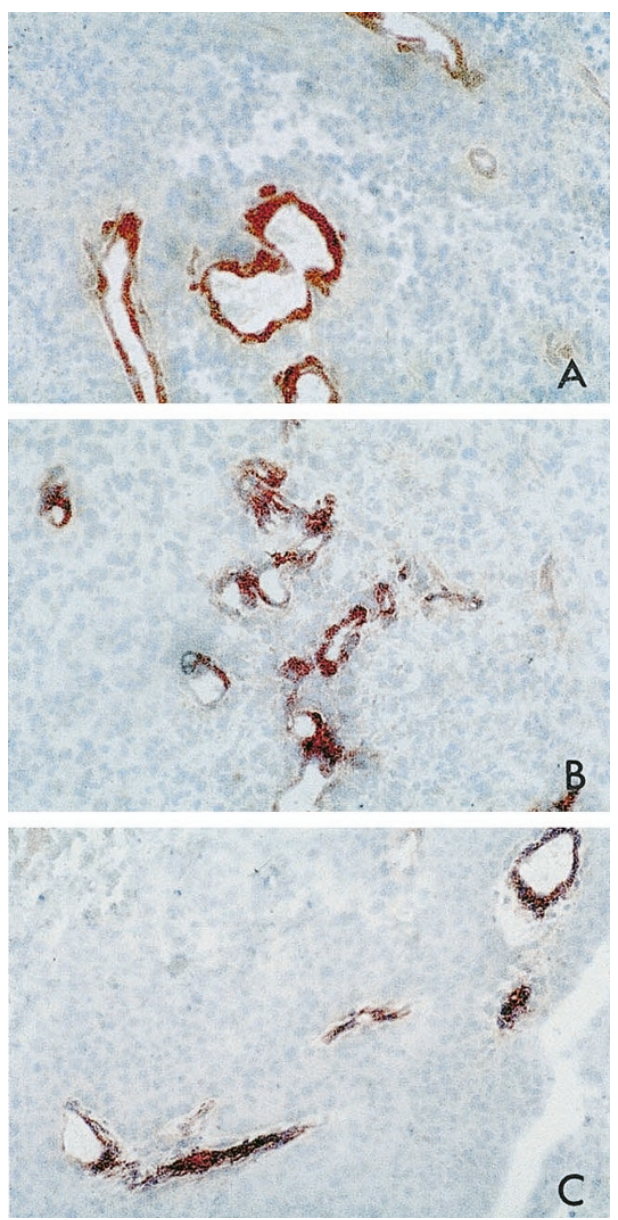

\section{Figure 2.}

APA activity in vessels of human brain tumors. Sections of frozen specimen of human brain tumors were exposed to specific Glu- $\beta$-methoxynaphthylamide substrate for aminopeptidase $\mathrm{A}$ in the presence of Fast Blue B. A, Glioblastoma; $B$, astrocytoma; $C$, metastatic carcinoma. Original magnification: $\times 250$.

static carcinoma (Fig. 2C), meningioma, oligodendroglioma, and neurinoma (not shown). However, high APA activity was not observed in all vessels of a tumor, and this difference is unrelated to the tumor origin and malignity; sometimes adjacent tumor vessels expressed different levels of APA activity (not shown). Evaluation of APB, APN, and $\gamma$ GTP within the same tumors indicated very low activity or activity below detection threshold in tumor vasculature for these three proteolytic activities (not shown), demonstrating a high specific activity only for APA in tumors and suggesting the preferential accumulation of Ang III among the angiotensin peptides.

An animal model of experimental rat glioblastoma was used to further evaluate in vivo the expression of aminopeptidases and the consequences of blocking angiotensin peptides generation. This model consisted in stereotactic transplantation of the rat glioma G2 cells in syngeneic rat brains, which induces the development of vasculature in the tumors (Reifenberger et al, 1989; Seitz et al, 1988). Lisinopril, a non-thiol ACE inhibitor, was given to rats from the day of tumor implantation until the day of death. Autopsy determined that blocking ACE activity did not inhibit tumor growth. In both the lisinopril-treated and untreated rats, the sizes and features of tumors were similar. High APA (Fig. 3A) and very low APB, APN, and $\gamma$-GTP (not shown) activities were observed in tumor vessels in both groups, similar to the observation made in human tumors, whereas surrounding normal brain tissue expressed low levels of APA activity (Fig. 3B).

To address the potential function of APA activity in brain tumor-associated vessels, the enzymatic activities of APA, APB, APN, and $\gamma$-GTP were evaluated in several brain-derived endothelial cell lines. From this screening, the EC219 cell line (Juillerat-Jeanneret et al, 1992), which displayed an enzymatic pattern similar to the vasculature of human brain tumors, was selected. The biochemical characteristics of APA and of enzymatic markers of cerebral endothelial cells were compared in this cell line and in freshly purified rat brain microvessels. The relative activity of APB was comparable in both samples. The activity of APA was higher in the EC219 cells than in microvessels, and $\gamma$ GTP activity was lower in EC219 cells than in the purified microvessels (Table 1). The $\mathrm{K}_{\mathrm{M}}$ values determined for APA $\left(K_{M}=2.1 \mu \mathrm{m}\right)$ were similar in both models (Fig. 4). The molecular weight of APA in the EC219 cells was approximately $150 \mathrm{kDa}$, as determined by gel filtration (not shown). Its enzymatic metalloprotease properties were demonstrated by inhibition of its activity only by EDTA ( $45 \%$ and $69 \%$ inhibition at 25 and $250 \mu \mathrm{m}$, respectively) and not by serine-, thiol- and aspartyl-protease inhibitors. These results show that the rat brain-derived endothelial EC219 cells express high level of APA with the same

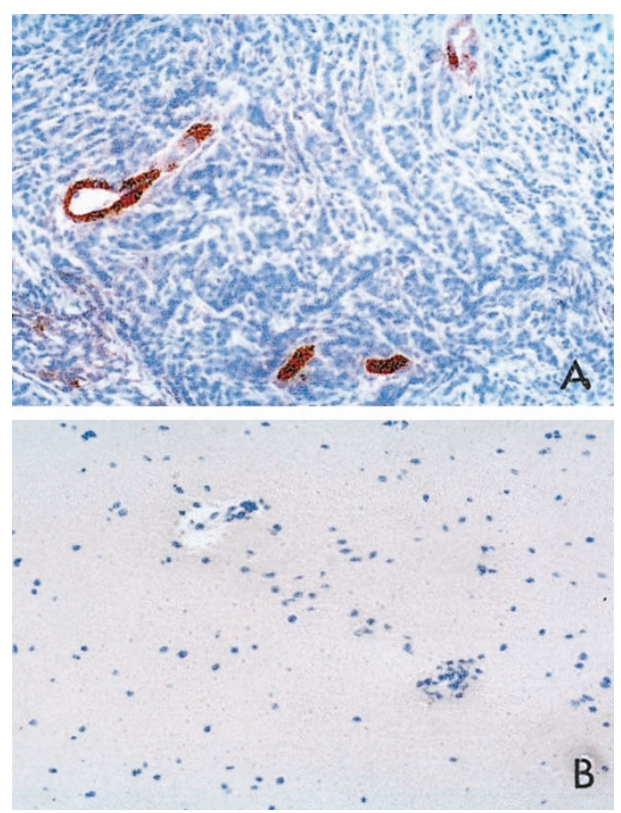

Figure 3.

Expression of APA enzymatic activity in an experimental rat glioblastoma cell model. Sections of frozen specimens of $(A)$ experimental brain tumor vessels and $(B)$ normal rat brain vessels were exposed to specific Glu- $\beta$ methoxynaphthylamide substrate for APA in the presence of Fast blue. Original magnification: $\times 250$. 
Table 1. Relative Activity of APA, APB, and $\gamma \mathrm{GTP}$ in Purified Microvessels and Brain-Derived Endothelial Cells EC219

\begin{tabular}{lcc}
\hline Enzymes & $\begin{array}{c}\text { Purified Microvessels } \\
{[\mathrm{U} / \mathrm{mg}]}\end{array}$ & $\begin{array}{c}\text { EC219 } \\
{[\mathrm{U} / \mathrm{mg}]}\end{array}$ \\
\hline APA & 5.8 & 30.4 \\
APB & 19.6 & 22.7 \\
$\gamma$ GTP & 50.7 & 12.7 \\
\hline
\end{tabular}

Purified rat brain microvessels or EC219 cells were extracted and protein and enzymatic activities were measured in duplicates in cell extracts

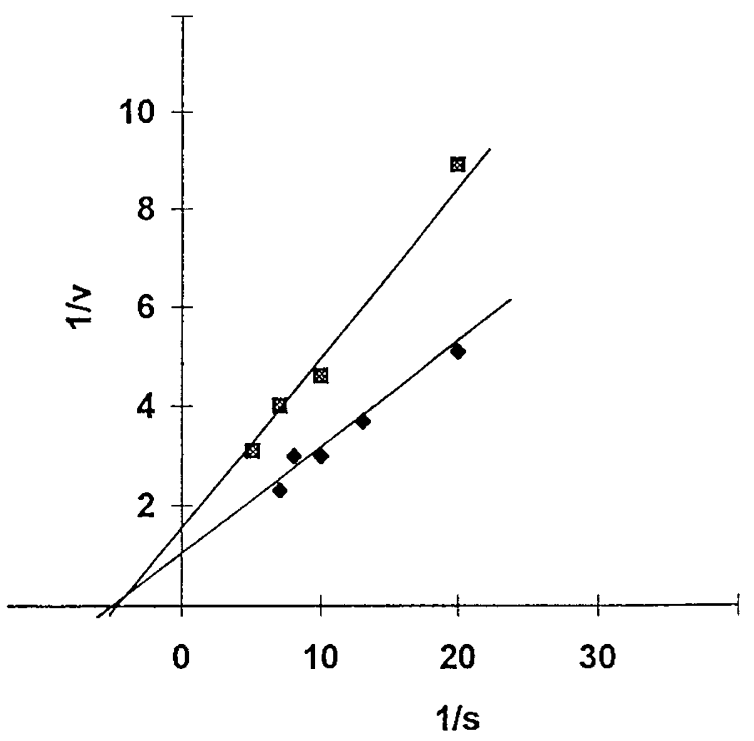

Figure 4.

$K_{M}$ determination for APA activity in extracts of EC219 cells and rat brain microvessels. Extracts of either rat brain microvessels $\mathbf{D}$ or EC219 rat brain endothelial cells - were exposed to increasing concentrations of the APA substrate Glu-pNA, and enzymatic activity was measured. Double reciprocal plots were drawn.

biochemical characteristics as purified rat microvessels.

APA activity did not stimulate proliferation of cerebral endothelial cells, as demonstrated by the lack of effect on thymidine incorporation and protein content in EC219 cells exposed for 3 days to 4 and $40 \mu \mathrm{m}$ amastatin, an APA inhibitor (not shown). This suggests that APA activity is not involved in endothelial proliferation.

Using EC219 cells grown on a semipermeable membrane, the APA substrate Glu-pNA was added either to the upper or the lower compartment. APA activity was found located preferentially in the upper compartment $(13.6 \pm 2.2 \mathrm{U} / \mathrm{ml})$ rather than in the lower compartment $(7.6+0.5 \mathrm{U} / \mathrm{ml})$, corresponding to a luminal rather than a basolateral location of APA.

The role of TGF $\beta$ and TGF $\beta$-secreting PROb tumor cells in APA regulation in cerebral endothelial cells was evaluated. The PROb tumor cells do not express APA activity, in contrast to the EC219 cells. The addition of recombinant TGF $\beta$ to EC219 cells, dose- dependently and time-dependently, decreased specific APA activity in EC219 cells (Fig. 5A). A similar result, while more effective in decreasing APA, was observed by co-culturing EC219 with the PROb cells (not shown). Under these conditions, no secretion of nitric oxide was observed (not shown). A doublereciprocal plot (Lineweaver and Burk plot) of the measured reaction rate in EC219 cells, exposed for 24 or 48 hours to increasing concentrations of TGF $\beta$, demonstrated that the kinetic constants $\left(\mathrm{K}_{\mathrm{M}}\right.$, measured on the $\mathrm{x}_{\text {axis }}$ ) of APA were not modified following 24 (not shown) or 48 hours exposure to $\operatorname{TGF} \beta$, whereas the amount of active enzyme (determined as
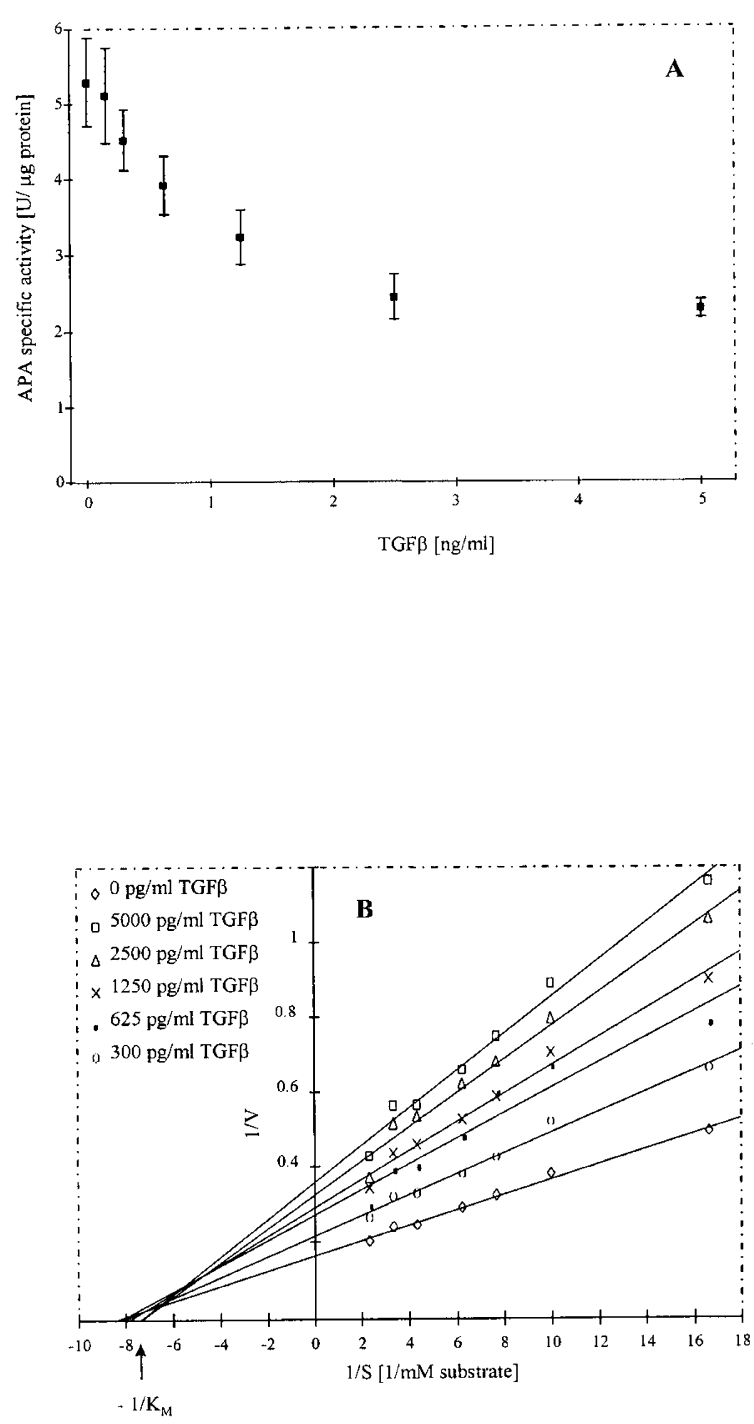

Figure 5.

TGF $\beta$ decreases the expression of active APA in APA-positive EC219 cells. $A$, EC219 cells were exposed for 48 hours to recombinant TGF $\beta$. APA activity was measured by fluorometry and units of enzymatic activity were related to the protein content. The same effects were observed following 24 hours exposure to TGF $\beta$ and co-culture with PROb cells (not shown). B, APA activity was measured in the presence of increasing concentration of substrate in extracts of EC219 cells exposed for 24 (not shown) or 48 hours to $\operatorname{TGF} \beta$, and a double-reciprocal plot was drawn. Experiments were performed in triplicates and were repeated 3 times. Results are given as mean \pm SD and are representative of one experiment. 
the inverse of $1 / \mathrm{N}$ on the $\mathrm{y}_{\text {axis }}$ ) was decreased (Fig. 5B).

\section{Discussion}

Angiotensin peptides not only regulate vascular tone and natriohydric balance, but are also involved in the control of vascular growth and permeability (Fernandez et al, 1985; Le Noble et al, 1991) and serve as neuromodulators. These various activities are exerted by different peptides of the angiotensin family, which are derived from a common precursor, angiotensinogen, by specific proteolytic processing. It has been recently shown that intake of the thiol ACE inhibitor captopril, but not other antihypertensive drugs, including non-thiol ACE inhibitors, decreases the risk of cancer in patients (Lever el al, 1998) and reduces tumor growth in experimental tumors in the rat, possibly by controlling angiogenesis (Prontera et al, 1999; Volpert et al, 1996). Thus, we addressed a potential role for angiotensin peptides in brain tumor. Because the very short half-life of angiotensin peptides in biological samples precludes the direct measurement of peptide concentrations in human surgical specimens, to define the precise angiotensin peptide involved, we instead determined the expression of the peptidases of the angiotensin cascade using histological sections of brain tumors.

The existence of the components of the reninangiotensin system has been documented in the brain, mainly in the rat (Ganong, 1993). Angiotensinogen mRNA is present in the brain in astrocytes, whose end-feet surround brain vessels, in neurons and in ependymal cells. Renin mRNA has been demonstrated in rat glial cells and neurons (Herman et al, 1987), and renin was also demonstrated by immunohistochemistry in glioblastoma tumors (Ariza et al, 1988). In the present experiments, we found renin in glioblastoma and cerebral parenchymal cells. ACE, which is widely expressed in the vascular system, is also expressed in vessels of brain tumors. Therefore, all the enzymes involved in Ang II production are present in the proximity of the brain tumor vessels.

The activity of APA, the enzyme generating Ang III from Ang II, was high in a subset of human brain tumor vessels. In the rat glioblastoma model, APA activity was higher in tumor vessels than in adjacent normal brain vessels. This, together with low levels of further Ang-degrading activity (aminopeptidase N/B activities) in the rat and human samples, suggests that Ang III predominantly accumulates around tumor vessels. APA activity in the rat brain was higher in the pituitary and circumventricular organs, which are located outside the blood-brain barrier, than in vessels located inside the blood-brain barrier (Zini et al, 1997), suggesting a role for this enzyme and Ang III in the lack of expression of blood-brain barrier properties. Ang II and Ang IV, but not Ang III, were shown to be involved in the maintenance of the blood-brain barrier (Kakinuma et al, 1998). Thus, depending on the particular pattern of protease expression and the angiotensin produced, blood-brain barrier function may not be maintained.

The anti-inflammatory glucocorticoid, dexamethasone, increases ACE expression (Fyhrquist et al, 1983; Juillerat-Jeanneret et al, 1992) and decreases APA activity (Juillerat-Jeanneret et al, 1992) in endothelial cells. Apparently, in brain endothelial cells, dexamethasone leads to a normal Ang II production. Interestingly, glucocorticoids reduce brain edema in patients with brain tumors, but not in patients with brain trauma, presumably because, in neoplasia, edema is predominantly vasogenic and related to dysfunction of blood-brain barrier (Long et al, 1966). These results suggest that glucocorticoids reduce brain tumorassociated edema by increasing ACE activity and decreasing APA activity, resulting in Ang II accumulation and restoration of the blood-brain barrier function (Kakinuma et al, 1998). Thus, in brain vasculature, a high APA activity may be a marker of the permanent loss of the metabolic functions of the blood-brain barrier. In normal situation, interactions between endothelial cells and pericytes result in a change from latent to active $\operatorname{TGF} \beta$ (reviewed in Darland and D'Amore, 1999), an anti-inflammatory peptide. The decrease in APA activity observed following exposure of EC219 cells to TGF $\beta$ demonstrates that this peptide is important in this context. Thus, we can hypothesize that, in cerebral tumor vasculature, the lack of TGF $\beta$ activation or the failure of a subset of endothelial cells to respond to TGF $\beta$, is responsible for the high APA activity that we observed in brain tumor vessels, resulting in an aberrant proteolytic processing of peptide hormones.

The APA-dependent generation of Ang III from Ang II is not directly involved in endothelial cell proliferation. In the rat glioblastoma model, intake of a nonthiol ACE inhibitor that specifically blocks only Ang II generation did not modify tumor progression and aminopeptidase expression in treated animals. In kidney mesangial cells, Ang II induces cell growth, which can be abolished by overexpression of APA and restored by the APA inhibitor amastatin (Wolf et al, 1997). This is an additional argument against Ang III as a cell growth-promoting peptide and a proliferative role for APA. Thus, both in vitro and in vivo experiments argue against a role in the growth of tumor vasculature for APA and Ang III.

In the present approach, we did not look for the expression of angiotensin receptors, because it was previously shown that Ang II and Ang III seem to use the same $A T_{1}$ receptors (Goodfriend et al, 1996). What, therefore, might be the significance of a predominant conversion of Ang II to Ang III? The half-life of Ang III is shorter than that of Ang II, so a high conversion of Ang II to Ang III would result in a decreased resistance of tumor vessels and a decreased perfusion of the tumor tissue. Ang II has also been shown to exert a pro-apoptotic effect for activated endothelial cells ( $\mathrm{Li}$ et al, 1999). It is not known whether Ang III shares this property. If not, the conversion of Ang II to Ang III might exert a protective role for tumor vasculature. 
In conclusion, we have demonstrated a high expression of APA activity associated with low APB/APN activity in brain tumor vessels, suggesting that Ang III is the bioactive hormone of the renin-angiotensin system in brain cancer. This modulation of aminopeptidase balance is not involved in endothelial cell growth but might result in increased vascular permeability, decreased tumor perfusion, and edema formation. APA may thus be a marker of a chronic dysfunction of the metabolic functions of the blood-brain barrier resulting from a lack of normal function of TGF $\beta$.

\section{Materials and Methods}

\section{Human Brain Samples}

Human brain tumors were obtained from surgical specimens. Resected tissues were immediately frozen and stored at $-80^{\circ} \mathrm{C}$. Tumor type and grading was done following routine histological examination performed for diagnostic purposes, according to the recommendations of the World Health Organization. For histoenzymography, at least four different tumors of each type and grading were examined. For immunohistology, brain tissue was obtained from autopsy specimens, fixed for one month in $10 \%$ formalin, and cut into 8 to $10 \mu \mathrm{m}$ sections using cryostat.

\section{Experimental Rat Glioblastoma Model}

Stereotactic grafting of 5000 rat glioblastoma RG2 cells was performed (D. Schüpbach, CHUV, Lausanne, Switzerland) in the right frontal brain of 8- to 10-week-old Fisher 344 syngeneic rats, as reported (Reifenberger et al, 1989; Seitz et al, 1988). Chronic ACE inhibitor treatment, using lisinopril, of 5 of 10 animals was performed as previously described (Juillerat-Jeanneret, 1993), starting on the day of tumor transplantation. Animals were killed on Day 20, and the brains were frozen and treated in the same manner as the human surgical specimens.

\section{Histochemistry}

Anti-renin monoclonal antibodies 2D12/F37 and 4G1/ F55 (Galen et al, 1984) were a gift from Sanofi-Pasteur, France. The antibody 2D12/F37 was used at a final concentration of $2 \mathrm{mg} / \mathrm{ml}$. As described previously (Galen et al, 1984), 4G1/F55 antibody did not recognize nonsoluble forms of renin and was used as a negative control for the determination of renin. The antihuman ACE monoclonal antibody 9B9 (Danilov et al, 1994) was a kind gift of Dr. S. Danilov (INSERM U367, Paris, France). Lyophilized antibody was dissolved in water $(1 \mathrm{mg} / \mathrm{ml})$ and used at a 1:150 dilution in PBS. Monoclonal anti-Factor VIII antibody was from DAKO (Hamburg, Germany). Histological slides were washed in PBS and incubated with the primary antibody, either overnight at $4^{\circ} \mathrm{C}$ or for 2 hours at room temperature, and subsequently with peroxidaseconjugated secondary antimouse immunoglobulin
(DAKO) for 30 minutes. Peroxidase activity was visualized using DAB $(0.035 \%)$ as a chromogen.

\section{In Situ Enzymatic Activities (Histoenzymography)}

Sections $(5 \mu \mathrm{m})$ of frozen brain tumor samples were exposed at $37^{\circ} \mathrm{C}$ to $\beta$-methoxynaphthylamide derivatives of specific substrates (Bachem, Switzerland) and Fast Blue B (Sigma, Switzerland), under the same conditions as previously described for cells (JuilleratJeanneret et al, 1992), and then counterstained with light hematoxylin reagent. Gamma-GTP was evaluated with $\gamma$-Glu- $\beta$-methoxynaphthylamide and GlyGly; APA, with $\alpha$-Glu- $\beta$-methoxynaphthylamide; APB, with Arg- $\beta$-methoxynaphthylamide; and APN/CD13, with Leu- $\beta$-methoxynaphthylamide. Enzymatic activity was visualized as a red precipitate.

\section{Endothelial Cell Culture and Treatment}

Preparation and culture conditions of rat brain-derived endothelial cells (EC219) have been previously described (Juillerat-Jeanneret et al, 1992). EC219 cells were grown for 3 days in the presence of 4 or $40 \mu \mathrm{m}$ of the aminopeptidase inhibitor, amastatin (Novabiochem, Laufelfingen, Switzerland), and the proliferation of cells was measured by incorporation of $\left[{ }^{3} \mathrm{H}\right]$ thymidine as previously described (Juillerat-Jeanneret et al, 1992) or by the protein content. At the end of the incubation period, APA inhibition was controlled. The culture conditions of EC219 cells on a semipermeable membrane $(0.45 \mu$ pore size) was performed as previously described (Juillerat-Jeanneret et al, 1992). The treatment of EC219 cells with TGF $\beta$ was performed as previously described (Murata et al, 1995). For coculture experiments, APA-negative (Murata et al, 1997) rat colon carcinoma PROb cells (a gift from F. Martin, Dijon) were seeded, together with APApositive (Juillerat-Jeanneret et al, 1992) rat cerebral endothelial EC219, and grown as a co-culture for 24 or 48 hours. APA activity was measured in cell extracts. Nitrite production was measured as previously described (Murata et al, 1995).

\section{Microvessel Preparation}

Microvessels were purified from rat brain cortices by mechanical dissociation and differential centrifugation, essentially as previously described for murine and porcine brain microvessels (Tontsch and Bauer, 1989). Gamma-GTP activity on smears of purified microvessels was measured to control the purity of the preparation.

\section{Determination of Active Renin Concentration}

Three to four million glioblastoma cells (Diserens et al, 1981) were washed with PBS, detached from the plate with a rubber policeman, and extracted by freeze/ thawing (3 times) in $1 \mathrm{ml}$ of $0.1 \mathrm{M}$ phosphate, $0.3 \mathrm{M}$ $\mathrm{NaCl}, \mathrm{pH}$ 8.0. Extracts were centrifuged, and the concentration of renin was measured in supernatants using an IRMA-renin determination kit (Sanofi- 
Pasteur, BioRad SDP, Reinach, Switzerland). In these conditions, all prorenin that might be present in the samples would have been activated by lysosomal proteases, because the renin determination method will measure only active renin.

\section{Determination of ACE Activity in Glioblastoma Cells}

ACE activity was measured in glioblastoma cell and microvessel extracts, using fluorogenic derivation with o-phthalaldehyde of His-Leu released from Z-PheHis-Leu by ACE as previously described (JuilleratJeanneret, 1993). ACE was purified from a pool of normal human plasma by affinity chromatography on a lisinopril-Sepharose column essentially as described (Bull et al, 1985). The purified enzyme was added to glioblastoma cell extracts before ACE activity determination to control for possible ACE inactivation.

\section{Soluble Aminopeptidase Enzymatic Activities}

Rat brain-derived microvessels or endothelial cells were extracted with $0.05 \mathrm{M}$ phosphate buffer, $\mathrm{pH} 8.0$, containing $0.15 \mathrm{M} \mathrm{NaCl}$ and $0.1 \%$ Triton $\mathrm{X}-100$. The enzymatic activities of the solubilized forms of $\gamma \mathrm{GTP}$, APA, APB, and APN (Juillerat-Jeanneret et al, 1992) were measured as previously described at $405 \mathrm{~nm}$ in a thermostated $\left(37^{\circ} \mathrm{C}\right)$ microtiter plate reader (iEMS; Labsystem, Helsinki, Finland) using $1 \mathrm{~mm}$ p-nitroanilide substrates (Bachem) in 0.1 M Tris buffer, $\mathrm{pH}$ 7.6. Inhibition studies were performed by adding the inhibitors at the indicated final concentration for 10 minutes at room temperature before adding the substrate. Alternatively, APA activity for the TGF $\beta$ experiments was measured fluorometrically using $0.15 \mathrm{~mm}$ Glu-AMC (Bachem) in 0.1 M Tris buffer, $\mathrm{pH} 7.6$, a thermostated microtiter plate reader (Cytofluor 4000; PerSeptive BioSystems, Cambridge, Massachusetts), and 360/460 nm filters for excitation and emission wavelengths. APA activities were related to the protein content (units of enzymatic activities/ $\mu \mathrm{g}$ protein). A double-reciprocal plot was drawn from the APA activity, which was measured using increasing concentrations of substrate in EC219 cell extracts following 24 or 48 hours exposure of cells to TGF $\beta$. Gel filtration studies were performed at $4^{\circ} \mathrm{C}$ using Sephadex G-100 (Pharmacia, Switzerland) in the extraction buffer.

\section{Protein Concentration}

Protein content was evaluated with the BCA protein assay kit (Pierce, Switzerland), using bovine serum albumin as standard.

\section{Acknowledgements}

The authors thank Mrs. P. Darekar and S. Burki for excellent technical and graphic assistance, Drs. D. Schüpbach and $\mathrm{H}$. Fankhauser for the gift of rat experimental glioblastoma, A. C. Diserens for providing the human glioblastoma cell cultures, and Drs. F. T. Bosman and R. C. Janzer for critical reading of the manuscript, evaluation of the histological samples, and very helpful suggestions. We are grateful to Dr. C. Cazaubon Sanofi-Pasteur, France, and Dr. S. Danilov, Inserm U367, France for kindly providing the antirenin and anti-ACE antibodies, respectively.

\section{References}

Ardaillou R and Chansel D (1997). Synthesis and effects of active fragments of angiotensin II. Kidney Int 52:1458-1468.

Ariza A, Fernandez LA, Inagami T, Kim JH, and Manuelidis EE (1988). Renin in glioblastoma multiform and its role in neovascularization. Am J Clin Pathol 90:437-441.

Bull HG, Thornberry NA, and Cordes EH (1985). Purification of angiotensin-converting enzyme from rabbit lung and human plasma by affinity chromatography. J Biol Chem 260: 2963-2972.

Danilov S, Jaspard E, Churakova T, Towbin H, Savoie F, Wei L, and Alhenc-Gelas F (1994). Structure-function analysis of angiotensin I-converting enzyme using monoclonal antibodies. Selective inhibition of the amino-terminal active site. J Biol Chem 269:26806-26814.

Darland DC and D'Amore PA (1999). Blood vessel maturation: Vascular development comes of age. J Clin Invest 103:157-158.

DeBault LE and Cancilla PA (1980). Gammaglutamyltranspeptidase in isolated brain endothelial cells: Induction by glial cells in vitro. Science 207:653-655.

Diserens AC, de Tribollet N, Martin-Achard A, Gaide AC, Schnegg JF, and Carrel S (1981). Characterization of an established human malignant glioma cell line: LN-18. Acta Neuropathol (Berl) 53:21-28.

Fernandez LA, Twickler J, and Mead A (1985). Neovascularization produced by angiotensin II. J Lab Clin Med 105:141145.

Fyhrquist F, Gronhagen-Riska C, Hortling L, Forslund T, and Tikkanen I (1983). Regulation of angiotensin converting enzyme. J Hypertens Suppl 1:25-30.

Galen FX, Devaux C, Atlas S, Guyenne TT, Ménard J, and Corvol P (1984). New monoclonal antibodies directed against human renin. Powerful tools for the investigation of the renin system. J Clin Invest 74:723-735.

Ganong WF (1993). Blood, pituitary, and brain reninangiotensin systems and regulation of secretion of anterior pituitary gland. Front Neuroendocrinol 14:233-249.

Goodfriend TL, Elliott ME, and Catt KJ (1996). Angiotensin receptors and their antagonists. N Engl J Med 334:16491654.

Herman K, Raizada MK, Sumners C, and Phillips MI (1987). Presence of renin in primary neuronal and glial cells from rat brain. Brain Res 437:205-213.

Joo F (1993). The blood-brain barrier in vitro: The second decade (Review). Neurochem Int 23:499-521.

Juillerat-Jeanneret L, Aguzzi A, Wiestler OD, Darekar P, and Janzer RC (1992). Dexamethasone selectively regulates the activity of enzymatic markers of cerebral endothelial cell lines. In Vitro Cell Dev Biol 28A: 537-543.

Juillerat-Jeanneret L (1993). Modulation of proteolytic activity in tissues following chronic inhibition of angiotensin converting enzyme. Biochem Pharmacol 45:1447-1454. 
Kakinuma Y, Hama H, Sugiyama F, Yagami KI, Goto K, Murakami K, and Fukamizu A (1998). Impaired blood-brain barrier function in angiotensinogen-deficient mice. Nat Med 4:1078-1080.

Le Noble FA, Hekking JW, Van Straaten HW, Slaaf DW, and Struyker Boudier HA (1991). Angiotensin II stimulates angiogenesis in the chorio-allantoic membrane of the chick embryo. Eur J Pharmacol 195:305-306.

Lever AF, Hole DJ, Gillis CR, McCallum IR, McInnes GT, MacKinnon PL, Meredith PA, Murray LS, Reid JL, and Robertson JW (1998). Do inhibitors of angiotensin converting enzyme protect against risk of cancer? Lancet 352:179-184.

Li D, Yang B, Philips MI, and Mehta JL (1999). Proapoptotic effects of Ang II in human coronary artery endothelial cells: Role of AT1 receptor and PKC activation. Am J Physiol 276:H786-H792.

Long DM, Hartmann JF, and French LA (1966). The response of human cerebral edema to glucosteroid administration. An electron microscopy study. Neurology 16:512-528.

Murata JI, Betz Corradin S, Felley-Bosco E, and JuilleratJeanneret $L$ (1995). Involvement of a transforming-growthfactor- $\beta$-like molecule in tumor cell-derived inhibition of nitric oxide synthesis in cerebral endothelial cells. Int $\mathrm{J}$ Cancer 62:743-748.

Murata JI, Ricciardi-Castagnoli P, Dessous L'Eglise Mange $P$, Martin F, and Juillerat-Jeanneret $L$ (1997). Microglial cells induce cytotoxic effects toward colon carcinoma cells: measurement of tumor cytotoxicity with a $\gamma$-glutamyl transpeptidase assay. Int J Cancer 70:169-174.

Prontera C, Mariani B, Rossi C, Poggi A, and Rotilio D (1999). Inhibition of gelatinase A (MMP-2) by batimastat and captopril reduces tumor growth and lung metastases in mice bearing Lewis lung carcinoma. Int $\mathrm{J}$ Cancer 81:761-766.
Reifenberger G, Bilzer T, Seitz RJ, and Wechsler W (1989). Expression of vimentin and glial fibrillary acidic protein in ethylnitrosourea-induced rat gliomas and glioma cell lines. Acta Neuropathol (Berl) 78:270-282.

Seitz RJ, Dechert M, and Wechsler W (1988). Vascularization of syngenic intracerebral RG2 and F98 rat tranplantation tumors. A histochemical and morphometric study by use of ricinus communis agglutinin I. Acta Neuropathol (Berl) 76: 599-605.

Tontsch U and Bauer HC (1989). Isolation, characterization, and long-term cultivation of porcine and murine cerebral capillary endothelial cells. Microvasc Res 37:148-161.

Volpert OV, Ward WF, Lingen MW, Chesler L, Solt DB, Johnson MD, Molteni A, Polverini PJ, and Bouck NP (1996). Captopril inhibits angiogenesis and slows the growth of experimental tumors. J Clin Invest 98:671-679.

Wolf G, Assmann KJM, and Stahl RAK (1997). Overexpression of aminopeptidase A abolishes the growth promoting effects of angiotensin II in cultured mouse mesangial cells. Kidney Int 52:1250-1260.

Zini S, Fournié-Zaluski MC, Chauvel E, Roques BP, Corvol P, and Llorens-Cortes C (1996). Identification of metabolic pathways of brain angiotensin II and III using specific aminopeptidase inhibitors: Predominant role of angiotensin III in the control of vasopressin release. Proc Nat Acad Sci, USA 93:11968-11973.

Zini S, Masdehors P, Lenkei Z, Fournié-Zaluski MC, Roques BP, Corvol P, and Llorens-Cortes C (1997). Aminopeptidase A: Distribution in rat brain nuclei and increased activity in spontaneously hypertensive rats. Neuroscience 78:11871193. 